einstein

Official Publication of the Instituto Israelita

de Ensino e Pesquisa Albert Einstein

ISSN: 1679-4508 | e-ISSN: 2317-6385

\title{
The delay of breast cancer diagnosis
} during the COVID-19 pandemic in São Paulo, Brazil

\author{
0 atraso no diagnóstico do câncer de mama durante a \\ pandemia da COVID-19 em São Paulo, Brasil
}

Bruna Mayumi Takaki Tachibana', Renato Leme de Moura Ribeiro', Érica Elisangela Françolin Federicci', Renata Feres' ${ }^{1}$, Felipe Antonio Sulla Lupinacci', Iviny Yonekura', Ana Claudia Silveira Racy ${ }^{1}$

${ }^{1}$ Hospital Israelita Albert Einstein, São Paulo, SP, Brazil.

DOI: 10.31744/einstein_journal/2021A06721

\section{ABSTRACT}

Objective: To evaluate the impact of COVID-19 pandemic on breast cancer diagnosis in a breast imaging center. Methods: This was a retrospective cohort study that included women submitted to breast exams and procedures in a private hospital in São Paulo, SP, Brazil, as from the period of most strict social isolation measures, in 2020 (separated in first period of social isolation, March 24 to June 21, 2020, and second period, June 22 to December 31, 2020), as compared to the same period in 2019. The number of exams, cancer detection rates, pathologic findings and risk factors were analyzed. Results: A total of 32,144 patients were included in the study. Breast imaging exams and procedures decreased by $78.9 \%$ in the first period, and $2.7 \%$ in the second period, in 2020. By the end of 2020, the number of breast cancer lesions detected was just six cases less than in 2019, although the number of patients submitted to mammograms was $35 \%$ lower. Conclusion: There was a drop in number of breast exams and cancer diagnoses in the first 90 days of the pandemic. The decrease in diagnosis of cancer was partially compensated in the second period, but the number of patients submitted to mammograms by the end of 2020 was lower, still considering a large number of patients with delayed exams.

How to cite this article: Tachibana BM, Ribeiro RL, Federicci EE, Feres R, Lupinacci FA, Yonekura I, et al. The delay of breast cancer diagnosis during the COVID-19 pandemic in São Paulo, Brazil. einstein (São Paulo). 2021;19:eA06721.

\section{Corresponding author:}

Bruna Mayumi Takaki Tachibana

Avenida Albert Einstein, 627/701 - Morumbi

Zip code: 05652-900 - São Paulo, SP, Brazil

Phone: (55 11) 2151-4271

E-mail: brunatakaki@gmail.com

Received on:

Apr 29, 2021

\section{Accepted on:}

July 26, 2021

Conflict of interest:

none.

Copyright 2021

\section{(c) BY}

This content is licensed

under a Creative Commons

Attribution 4.0 International License.

Keywords: COVID-19; Coronavirus infections; Breast neoplasms; Early detection of cancer; Mammography; Magnetic resonance spectroscopy; Ultrasonography, mammary; Prognosis; Breast cancer screening; Brazil

\section{RESUMO}

Objetivo: Avaliar o impacto da pandemia da COVID-19 no diagnóstico de câncer de mama em um centro de imagem de mama. Métodos: Estudo de coorte retrospectivo que incluiu mulheres submetidas a exames e procedimentos de mama em um hospital privado em São Paulo, SP, Brasil, no período de medidas mais rigorosas de isolamento social em 2020 (dividido em primeiro período, de 24 de março a 21 de junho de 2020, e em segundo período, de 22 de junho a 31 de dezembro de 2020), comparado com o mesmo período de 2019. Foram analisados o número de exames, as taxas de detecção de câncer, os achados patológicos e os fatores de risco. Resultados: Foram incluídas 32.144 pacientes. Os exames e os procedimentos de imagem da mama em 2020 tiveram redução de 78,9\% no primeiro período e 2,7\% no segundo período. Ao final de 2020, foram diagnosticadas com câncer de mama seis pacientes a menos do que em 2019, embora 0 número de pacientes submetidas à mamografia tenha sido $35 \%$ menor. Conclusão: Houve queda no número de exames de mama e de diagnósticos de câncer nos primeiros 90 dias da pandemia. A redução dos diagnósticos de câncer foi parcialmente compensada no segundo período, mas o número de pacientes submetidas a exames de mamografia até o final do ano foi menor, considerando ainda um grande número de pacientes com exames atrasados. 
Descritores: COVID-19; Infecções por coronavírus; Neoplasias da mama; Detecção precoce de câncer; Mamografia; Espectroscopia de ressonância magnética; Ultrassonografia mamária; Prognóstico; Rastreamento de câncer de mama; Brasil

\section{INTRODUCTION}

From December 2019 to March 2021, severe acute respiratory syndrome coronavirus 2 (SARS-CoV-2) has caused more than 115 million cases of coronavirus disease 2019 (COVID-19) and over 2.5 million deaths across the world. ${ }^{(1)}$ Countries with significant outbreaks, including Brazil, have introduced social distancing or lockdown measures to flatten the curve of incidence of the COVID-19 pandemic, and reduce the potential impact on health care systems. By April 2020, about half of the world's population was under lockdown, with over 3.9 billion people in more than 90 countries or territories having been asked or ordered to stay at home by their governments. ${ }^{(2,3)}$

To secure the health of patients and staff and preserve vital resources within the health care system, health care organizations and providers have been instructed to stop performing elective surgical procedures. Furthermore, the American College of Radiology (ACR) has endorsed the guidance from the Centers for Disease Control and Prevention (CDC) to reschedule nonurgent outpatient visits. ${ }^{(4)}$ Organizations related to breast cancer diagnosis and treatment also published recommendations for scheduling breast imaging exams and breast cancer treatment during the COVID-19 pandemic. The guidelines were initially to "cancel elective and non-urgent procedures, except those applied to evaluate urgencies, such as abscesses and postoperative complications."(5)

Amid the increasing number of COVID-19 cases and similar to other international healthcare providers, the Brazilian Colégio Brasileiro de Radiologia (CBR), in association with the Brazilian Federação Brasileira das Associações de Ginecologia e Obstetrícia (FEBRASGO) and the Sociedade Brasileira de Mastologia (SBM), published a note on March 26, 2020 with recommendations for scheduling breast imaging exams during the COVID-19 pandemic, stating all exams that could be postponed should be avoided, especially in patients aged over 60 years. The advice was very clear addressing all breast exams should be carefully assessed, including screening exams.

In this context, specifically the fear of an unknown and highly transmissible virus, many patients have postponed their breast imaging exams and medical care. There was a drop in all exams, increasing the risk of delayed diagnosis to patients. In July 2020, ACR published recommendations for the cautious recovery and resumption of all types of imaging practices. ${ }^{(6)}$

During 2020, there were many fluctuations in the number of cases of COVID-19 and, consequently, in the recommendations for social distance. The population has been waiting for the right moment to return to their usual routine and perform their exams, but much instability has been observed in the number of cases up to the present moment, including new strains of the COVID-19 circulating in the population. ${ }^{(7)}$

\section{History of breast cancer and COVID-19 in our organization}

Breast cancer is a very prevalent disease in the world, and it is not different in Brazil. According to data from the Brazilian Ministry of Health and the Instituto Nacional de Câncer José Alencar Gomes da Silva (INCA), it was estimated that 66,280 new cases would be diagnosed in Brazil, in 2020. Breast cancer is the major primary cause of death from neoplasms in women in our country, accounting for $16.4 \%$ of cases (17,572 deaths per year). ${ }^{(8)}$ One of the major public health challenges is to diagnose and treat the cancer as early as possible, increasing the patient's disease-free survival and life expectancy.

According to the American Cancer Society's (ACS) biennial update on female breast cancer statistics, the 5 -year survival rate is $91 \%$. However, survival decreases greatly if patients develop distant metastases. The overall 5-year relative survival rate is $99 \%$ for localized disease, and $86 \%$ for regional disease, which drops to $27 \%$ for distant- metastasis stage disease. ${ }^{(9)}$ A breast cancer diagnosed at a more advanced stage may change from having a curable (with near-normal life expectancy) to incurable disease.

The first registered case of COVID-19 in Brazil was diagnosed at our organization on February 26, 2020, in a patient returning from a trip to Italy. Since then, the number of COVID-19 cases and deaths has increased in Brazil, with more than 16 million people diagnosed and more than 470 thousand deaths by the end of May, 2021. ${ }^{(10)}$ The city of São Paulo (SP, Brazil) has 12.2 million inhabitants, and registered over 799 thousand cases and 31 thousand deaths by the same date.

The Hospital Israelita Albert Einstein (HIAE) is a quaternary care hospital, with a 579-bed capacity. The imaging department predominantly serves the hospital 
performing exams in hospitalized and emergency department patients. It also has an outpatient center in charge of the majority of breast imaging exams.

Previous studies about the reduced volume of imaging exams have already demonstrated diminished numbers of breast imaging exams ${ }^{(11-14)}$ during the pandemic. However, these studies do not make a clear analysis with data by the end of the year, when the population started to receive warnings about the importance of returning to routine exams, and tried to resume their activities with safety precautions for COVID-19.

\section{OBJECTIVE}

To evaluate the impact of COVID-19 pandemic on breast cancer diagnosis in a breast imaging center.

\section{METHODS}

This cohort study included patients from the Imaging Department of HIAE, who underwent breast exams (mammography, magnetic resonance imaging - MRI -, ultrasonography, and invasive procedures) in the first and in the second period of social isolation in our state, respectively, from March 24 to June 21, 2020 and from June 22 to December 31, 2020, compared with the same periods during March 24 to December 31, 2019. The research project was submitted to the Research Ethics Committee of HIAE, protocol 4,321,537, CAAE: 37227920.8.0000.0071. No Informed Consent Forms were obtained. The request for waiver of Informed Consent Form was accepted considering it was retrospective study with anonymized data.

A search for the breast exams was performed using a business intelligence tool and our radiology information system. Data collection included age of patients, the number of newly diagnosed breast cancers, Breast Imaging Reporting and Data System (BI-RADS ${ }^{\circledR}$ ) final assessment, ${ }^{(15)}$ number and results of biopsies, histological and molecular type of the tumors, and risk factors of the patients. Patients diagnosed with malignant breast lesions were classified in symptomatic (presenting with palpable lesions, nipple discharge, nipple retraction and symptoms of metastatic lesions), asymptomatic with increased risk of breast cancer (considering personal or family history including mother, sister, daughter, aunt or first-degree male relatives) and asymptomatic with no increased risk. Information about the symptoms was gathered from the questionnaires that each patient filled out before the procedure. We excluded mammograms with incomplete data in their reports from the BI-RADS ${ }^{\circledR}$ analysis.

Data were presented in absolute and relative frequencies, median and range, and statistical analyses were made using the $\chi^{2}$, likelihood ratio, and Student's $t$ tests. The data analysis for this study was generated using the software (SPSS) for Windows, version 26.0 (IBM Corp., Armonk, NY, United States). ${ }^{(16)}$

\section{॥ RESULTS}

This study included 32,114 patients from our breast imaging center; in that, 15,888 patients during the pandemic period (March 24 to December 31, 2020) and 23,110 patients during the comparison period (March 24 to December 31, 2019), and 6,884 were seen in both years. A total of 27,215 breast imaging exams (mammography, MRI, ultrasonography, and invasive procedures) were performed at our organization in 2020 (March 24 to December 31), compared with 37,968 exams in 2019 during the same period. Table 1 compares the exams performed during the studied period of 2020 and corresponding period of 2019, categorized by type (Table 1).

In the first period, we had a significant drop in all exams, more evident in the mammograms. In the second period, the decrease in mammography and ultrasonography was lower than in the first period, and an increase in MRI and biopsies was observed $\left(\chi^{2}\right.$ test, $\mathrm{p}<0.001)$.

Table 1. Exams performed during period of 2020 and corresponding period of 2019, categorized by type

\begin{tabular}{lccc}
\hline Periods & $\mathbf{2 0 1 9}$ & $\mathbf{2 0 2 0}$ & Increase/decrease \\
\hline First period* & & & \\
Mammography & 5,844 & 948 & -83.8 \\
Ultrasonography & 6,298 & 1,513 & -76.0 \\
MRI & 478 & 141 & -70.5 \\
Biopsies & 219 & 105 & -52.1 \\
Total & 12,839 & 2,707 & -78.9 \\
Second period* & & & -4.7 \\
Mammography & 10,379 & 9,891 & -2.5 \\
Ultrasonography & 12,970 & 12,644 & +4.8 \\
MRI & 1,003 & 1,051 & +18.3 \\
Biopsies & 518 & 613 & -2.7 \\
\hline Total & 24,870 & 24,199 & \\
\hline Results expressed as $n$ or \%. \\
* First period corresponded to the first 90 days of social isolation (March 24 to June 21, 2020) due to CoviD-19 pandemic. \\
The second period corresponded to CoviD-19 pandemic after the first 90 days of social isolation, by the end of the year \\
(June 22 to December 31, 2020).
\end{tabular}


The number of mammograms dropped sharply in the first period and gradually returned to baseline parameters, more significantly in May. In September it surpassed the number of exams from the previous year (Figure 1).

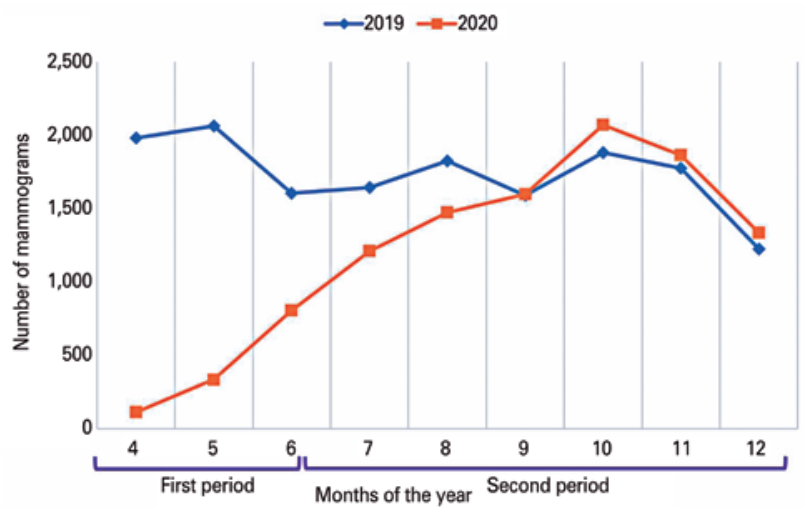

Figure 1. A gradual increase in the number of exams in 2020 is observed, after the sharp reduction in March and April. As from September, the number of mammograms during the pandemic (2020) was higher than in the pre-pandemic period (2019)

From the total of 34,603 mammograms, we excluded 1,525 exams in 2020 and 2,842 in 2019 , due to missing data of the BI-RADS ${ }^{\circledast}$ final assessment in our radiology information system.

The mean age of the patients submitted to mammography during the pandemic was lower (50.44) than in the same period of 2019 (52.11), with $\mathrm{p}<0.001$. During the second period, there was no statistically significant difference (Table 2).

Table 2. Overall analysis during the first and second periods, March 24 to December 31, 2019 and March 24 to December 31, 2020

\begin{tabular}{|c|c|c|c|c|c|c|}
\hline \multirow[b]{2}{*}{ Findings } & \multicolumn{3}{|c|}{$1^{\text {st }}$ period } & \multicolumn{3}{|c|}{$2^{\text {nd }}$ period } \\
\hline & 2019 & 2020 & $\begin{array}{c}\mathbf{p} \\
\text { value }\end{array}$ & 2019 & 2020 & $\begin{array}{c}p \\
\text { value }\end{array}$ \\
\hline $\begin{array}{l}\text { Patients } \\
\text { submitted to } \\
\text { mammography }\end{array}$ & 5,661 & 927 & & 10,155 & 9,394 & \\
\hline Age $^{*}$ & $52.1 \pm 11.24$ & $50.4 \pm 10.27$ & $<0.001$ & $51.5 \pm 11.04$ & $51.7 \pm 10.76$ & 0.218 \\
\hline $\begin{array}{l}\text { BI-RADS }{ }^{\circledast} \\
\text { and } 5^{\dagger}\end{array}$ & 2.7 & 6.2 & $<0.001$ & 3.2 & 3.9 & 0.014 \\
\hline Breast cancer & 36 & 18 & & 98 & 110 & \\
\hline $\begin{array}{l}\text { Breast } \\
\text { cancer/1,000 } \\
\text { patients }^{\ddagger}\end{array}$ & 6.4 & 19.4 & $<0.001$ & 9.7 & 11.7 & 0.165 \\
\hline $\begin{array}{l}\text { Symptomatic or } \\
\text { elevated risk }\end{array}$ & 55.6 & 88.9 & 0.016 & 61.2 & 60.0 & 0.857 \\
\hline $\begin{array}{l}\text { Aggressive } \\
\text { subtypes' }\end{array}$ & 19.4 & 27.8 & 0.5 & 14.3 & 8.2 & 0.2 \\
\hline
\end{tabular}

Results expressed as $n$, mean age \pm standard deviation or \%

* Mean age of patients submitted to mammography (standard deviation); ${ }^{\dagger}$ BI-RADS ${ }^{\star} 4$ and 5 among BI-RADS ${ }^{\circledR} 1,2,3$ and $4 ;{ }^{\ddagger}$ rate of breast cancer/patients submitted to mammography; ${ }^{\S}$ percentage of breast cancer in patients presenting symptoms or elevated risk; ' percentage of more aggressive molecular subtypes (Her-2 and triple-negative).
Considering the mammography BI-RADS ${ }^{\circledR}$ final assessment, we found in the first and second periods of 2020 a decreased percentage of BI-RADS ${ }^{\circledR} 1$ and 2 , and an increase of BI-RADS ${ }^{\circledR} 4$ and 5 , as shown in table 3 .

Among the mammograms with final assessment BI-RADS ${ }^{\circledR} 4$ and 5, we observed an increased proportion of patients in the age range of 61 to 70 years during the pandemic (Figure 2).

Table 3. Classification of the mammographies as BI-RADS ${ }^{\circledR} 1$ and 2 and BI-RADS $^{\circledR} 4$ and 5 , separated by year

\begin{tabular}{lccc}
\hline Period & $\mathbf{2 0 1 9}$ & $\mathbf{2 0 2 0}$ & p value \\
\hline First period & & & \\
BI-RADS $^{\circledR} 1$ and 2 & $4,797(97.3)$ & $693(93.8)$ & \\
BI-RADS $^{\circledR} 4$ and 5 & $131(2.7)$ & $46(6.2)$ & \\
Total & $4,928(100)$ & $739(100)$ & $<0.001$ \\
Second period & & & \\
BI-RADS 1 and 2 & $8,181(96.8)$ & $8,239(96.1)$ & \\
BI-RADS ${ }^{\circledR}$ and 5 & $272(3.2)$ & $336(3.9)$ & \\
Total & $8,453(100)$ & $8,575(100)$ & 0.014 \\
\hline
\end{tabular}

Results expressed as $n(\%)$

In 2020, in both periods, we observed an increase in the proportion of exams classified as BI-RADS 4 and 5 in relation to BI-RADS ${ }^{\circledR} 1$ and 2 when comparing to 2019. $\chi^{2}$ test, $p<0.001$ (first period)/ $p=0.014$ (second period).

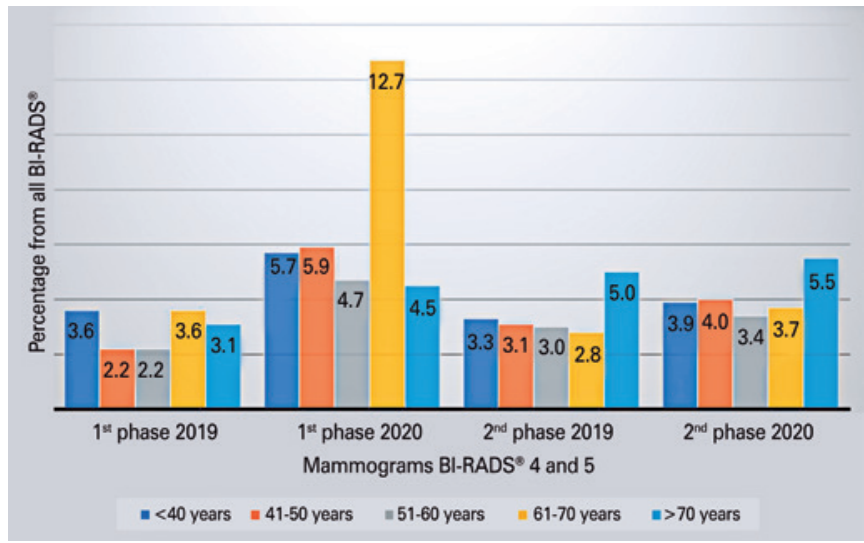

Figure 2. Percentage of mammograms with final assessment BI-RADS ${ }^{\circledR} 4$ and 5 , separated by periods and age groups. An increase in the frequency of exams classified as BI-RADS ${ }^{\circledast} 4$ in patients aged 61 to 70 years was observed in the first period of 2020, compared to the others $(p=0.341)$

The number of malignant breast lesions diagnosed in 2020 was 130 (18 and 112 in the first and second periods, respectively), and, in 2019, it was 138 (37 and 101 in the first and second periods, respectively). Among the malignant lesions, six cases were not considered as breast cancer (three cases of lymphoma and three cases of methastatic lesions). 
A higher rate of breast cancer/1,000 patients submitted to mammograms was observed in 2020, as compared to the same period in 2019 (Table 4).

Table 4. Comparison of breast cancer detection / patients submitted to mammography, separated by year (2019 and 2020), during the first (March 24 to June 21) and second (June 22 to December 31) periods

\begin{tabular}{|c|c|c|c|c|c|c|c|}
\hline \multirow{2}{*}{$\begin{array}{l}\text { Period } \\
\text { of the } \\
\text { year }\end{array}$} & \multicolumn{3}{|c|}{2019} & \multicolumn{3}{|c|}{2020} & \multirow[b]{2}{*}{ p value } \\
\hline & $\begin{array}{l}\text { Breast } \\
\text { cancer }\end{array}$ & $\begin{array}{c}\text { Number of } \\
\text { mammography }\end{array}$ & $\begin{array}{l}\text { Rate/ } \\
1,000 \\
\end{array}$ & $\begin{array}{l}\text { Breast } \\
\text { cancer }\end{array}$ & $\begin{array}{c}\text { Number of } \\
\text { mammography }\end{array}$ & $\begin{array}{l}\text { Rate/ } \\
1,000\end{array}$ & \\
\hline $\begin{array}{l}\text { First } \\
\text { period }\end{array}$ & 36 & 5,661 & 6.4 & 18 & 927 & 19.4 & $<0.001$ \\
\hline $\begin{array}{l}\text { Second } \\
\text { period }\end{array}$ & 98 & 10,155 & 9.7 & 110 & 9,394 & 11.7 & 0.165 \\
\hline $\begin{array}{l}\text { Both } \\
\text { periods }\end{array}$ & 134 & 15,816 & 8.5 & 128 & 10,321 & 12.4 & 0.002 \\
\hline
\end{tabular}

Among the patients diagnosed with breast cancer in the first period of $2020,88.9 \%$ of them had symptoms related to the disease (including palpable lesions, nipple discharge, nipple retraction, and symptoms of metastatic lesions), or increased risk of breast cancer (considering past or family history including mother, sister, daughter, aunt) as compared to 55.6\%, in 2019.

Considering the molecular subtypes of breast cancer, there was an increase in the frequency of more aggressive subtypes in the first phase of 2020 (27.8 versus 19.4 in the previous year), although with no statistically significant association.

\section{DISCUSSION}

The COVID-19 pandemic has certainly several consequences on the world's health, many of which have yet to be measured.

This study shows the pandemic caused a global reduction of $78.9 \%$ in breast imaging exams and procedures in our department during the first 90 days of social isolation (March 24 to June 21, 2020), as compared to the previous year. The findings of our study are remarkably consistent with the literature, reporting reduced demand for health care during the pandemic, including emergency services during the first months of the pandemic. ${ }^{(17)}$ Naidich et al., observed the greatest decline in imaging volume during the pandemic was specifically for outpatient imaging (88\%), affecting all modalities - but more pronounced in mammography exams (94\% less than 2019)..$^{(11)}$
In the first period of 2020, the evidence of a higher frequency of BI-RADS ${ }^{\circledR} 4$ and 5 compared to 1 and 2, and decreased mean age of patients who underwent mammograms, associated with the large increase in the number of breast cancers/1,000 patients, demonstrate, at this stage, the patients who underwent the exams were those who really required them.

This is reinforced when we observe the analysis of malignant lesions, which were more associated to patients with symptoms or increased risk, and more aggressive subtypes than in the previous period (2019).

This finding is in accordance with the study by Al-Thoubaity, which proved the most aggressive subtypes of breast cancer presented with a higher histological grade and larger tumor size upon diagnosis; hence, more likely to be symptomatic. ${ }^{(18)}$

The higher frequency of BI-RADS ${ }^{\circledR} 4$ and 5 mammograms among patients aged 61 to 70 years, in the first period of 2020, can also show most patients in this age group stayed at home, and those who came presented with suspicious findings. Older patients were expected to be affected more with the pandemic restrictions, since social isolation recommendations described this group as high risk for developing more severe clinical pictures of COVID-19 infections.

Based on our findings, we estimated approximately 18 patients from our organization may have had a delayed diagnosis of breast cancer during the first 90 days of the social isolation (a drop by $50 \%$ compared to 2019). Similar to our department, public health systems in other countries also have documented a reduction in cancer detection in the first period of the pandemic. The Netherlands Cancer Registry reported a drop in cancer incidence by up to $40 \%$ in the last few weeks during the pandemic. ${ }^{(19)}$ According to the Cancer Research Unided Kingdom, the number of urgent cancer referrals in England has reduced by $75 \%$ since restrictions were implemented. ${ }^{(20)}$

In the second period, the increased proportion observed in MRI and biopsies related to mammography and ultrasonography may reflect greater complexity of the cases, associated to the higher rate of cancer/ mammograms as compared to 2019.

The number of breast cancer diagnosis in the second period of the pandemic was higher than in the previous year (110 versus 98 ); however, the number of mammograms remained a little lower.

Considering the period March 24 to December 31, the total number of breast cancer in 2020 was just six cases less than in 2019. 
The findings of our study suggest there was a delay in the breast cancer diagnosis during the first period of the pandemic, which was partially compensated for in the second.

Nonetheless, we are still concerned about the total number of patients undergoing mammographic examinations remaining 35\% below the previous year. Although these may be patients who would have normal exams and would not have malignant diagnoses, if we consider the rate of 8.5 cases $/ 1,000$ mammograms in 2019, we estimate 46.7 cases of undiagnosed cancer in 2020 (35.9\% of total diagnosed since the beginning of the pandemic).

We have not been able to measure the impact of the pandemic in diagnosis of breast cancer in our population. But some evidence points to a worse prognosis due to late diagnosis. The delay in breast cancer diagnosis probably contributes to more advanced stages upon presentation, leading to poorer clinical outcomes. Maringe et al., in a population-based modelling study, estimated an increase by $7.9 \%$ to $9.6 \%$ in deaths due to breast cancer up to 5 years after diagnosis, due to delayed diagnosis caused by the pandemic. ${ }^{(21)}$

Currently in the pandemic, health systems and facilities are more prepared to receive patients for exams. Hospitals and health facilities are more structured with safety protocols adapted for the prevention of COVID-19 transmission. ${ }^{(6,21,22)}$ Benefits from breast screening exams outweigh the risk of COVID-19 infection. In this scenario, as breast societies keep advising about the importance of returning to screening exams, we need to do an intense and effective effort so that patients really feel safe enough to return to their breast exams.

Strategies are needed to encourage women to perform postponed breast imaging screening exams, and prepare our team to perform more exams than usual, thus avoiding further delays in diagnosis of breast cancer.

We have to consider the delay in breast exams not only in terms of returning to the usual number of exams, but also addressing how to mitigate the effects of delay in diagnosis.

One limitation of our study was the reduced number of patients and exams during the first period of the pandemic. However, analyzing this reduced number of patients was, in fact, one of the objectives of our work.

To date, this is the first study to analyze the impact of the pandemic in health care of a population seen at a breast cancer diagnostic center, comparing differences in the volume of exams and diagnoses in 2020 and 2019, as from the first days of social isolation until the end of the year, separated into two periods, and assessing the consequences in 2020 due to the pandemic.

\section{CONCLUSION}

The study showed a large drop in the number of breast exams and cancer diagnoses in the first 90 days of the pandemic, with a greater number of patients with suspicious and malignant findings. In the second period, there was a partial compensation of the number of cancer diagnoses and, by the end of the year, the number of breast cancers detected was only six less than in 2019, although the number of patients submitted to mammograms was lower. Future studies may measure the damage caused by the pandemic in treatment and prognosis, secondary to delay of exams and diagnoses.

\section{Practice points}

This study reveals an overall $78.9 \%$ decrease in breast imaging exams and procedures, and a 50\% decrease in cancer diagnoses in our department, during the first 90 days of social isolation.

During the first period of the pandemic, patients submitted to mammograms were younger and the number of cancers detected per mammography was three times higher $(19.4 / 1,000)$ than in 2019 $(6.4 / 1,000)$.

During both periods of the pandemic (2020), we had an increase in the proportion of the exams classified as BI-RADS ${ }^{\circledR} 4$ and 5 in relation to BI-RADS ${ }^{\circledR} 1$ and 2 when comparing to 2019.

By the end of the year, there were six cases less of cancer detected in comparison to the previous year, although the number of patients who underwent mammography was $35 \%$ lower, with 5,495 patients less performing the exams in 2020 .

\section{AUTHORS' CONTRIBUTION}

Bruna Mayumi Takaki Tachibana: conceptualization, methodology, software, formal analysis, resources, data curation, writing of original draft, project administration. Renato Leme de Moura Ribeiro: conceptualization, methodology, validation, writing - review \& editing. Érica Elisangela Françolin Federicci: conceptualization, methodology, writing - review \& editing. Renata Feres: conceptualization and methodology. Felipe Antonio 
Sulla Lupinacci: conceptualization and methodology. Iviny Yonekura: methodology, writing - review \& editing. Ana Claudia Silveira Racy: writing - review \& editing, supervision.

\section{AUTHORS' INFORMATION}

Tachibana BM: http://orcid.org/0000-0001-8820-2456

Ribeiro RL: http://orcid.org/0000-0002-2311-9835

Federicci EE: http://orcid.org/0000-0001-7013-4168

Feres R: http://orcid.org/0000-0003-0152-276X

Lupinacci FA: http://orcid.org/0000-0002-3896-1478

Yonekura I: http://orcid.org/0000-0003-2812-1632

Racy AC: http://orcid.org/0000-0002-4054-8236

\section{REFERENCES}

1. World Health Organization (WHO). WHO Coronavirus Disease (COVID-19) dashboard. Geneva: WHO; 2021 [cited 2021 Apr 2]. Available from: https:// covid19.who.int/

2. Sandford A. Coronavirus: half of humanity now on lockdown as 90 countries call for confinement. Lyon: Euronews; 2020 [updated 2020 Apr 3] [cited 2020 0ct 14]. Available from: https://www.euronews.com/2020/04/02/ coronavirus-in-europe-spain-s-death-toll-hits-10-000-after-record-950-newdeaths-in-24-hou

3. Kaiser Family Foundation (KFF). Coronavirus (COVID-19). State COVID-19 data and policy actions. São Francisco: KFF; 2021 [updated 2021 June 14] [cited 2021 Apr 10]. Available from: https://www.kff.org/coronavirus-covid-19/ issue-brief/state-covid-19-data-and-policy-actions/

4. American College of Radiology (ACR). ACR COVID-19 clinical resources for radiologists. Reston: ACR; s.d [cited 2020 Nov 3]. Available from: https:// www.acr.org/Clinical-Resources/COVID-19-Radiology-Resources

5. Society of Breast Imaging (SBI). Society of Breast Imaging statement on screening in a time of social distancing. Reston (USA): SBI; 2020 [updated 2020 Mar 18] [cited 2020 Nov 14]. Available from: https://www.sbi-online. org/Portals/0/Position Statements/2020/SBI-statement-on-screening-in-atime-of-social-distancing_March-17-2020.pdf

6. Davenport MS, Bruno MA, Iyer RS, Johnson AM, Herrera R, Nicola GN, et al. ACR statement on safe resumption of routine radiology care during the Coronavirus Disease 2019 (COVID-19) pandemic. J Am Coll Radiol. 2020;17(7):839-44.

7. Centers for Disease Control and Prevention (CDC). About variants of the virus that causes COVID-19. Atlanta (USA): CDC; 2021 [updated 2021 June 24] [cited 2021 Apr 4]. Available from: https://www.cdc.gov/coronavirus/2019ncov/transmission/variant.htm
8. Brasil. Ministério da Saúde. Instituto Nacional de Câncer José Alencar Gomes da Silva (INCA). Estatísticas de câncer. Rio de Janeiro: Ministério da Saúde; INCA; 2021 [citado 2021 Abr 8]. Disponível em: https://www.inca.gov.br/ numeros-de-cancer

9. Wang R, Zhu Y, Liu X, Liao X, He J, Niu L. The clinicopathological features and survival outcomes of patients with different metastatic sites in stage IV breast cancer. BMC Cancer. 2019;19(1):1091.

10. Brasil. Ministério da Saúde. Departamento de Informática do Sistema Único de Saúde do Brasil (DATASUS). Painel geral. Painel de casos de doença pelo coronavírus 2019 (COVID-19) no Brasil. Brasília (DF): Ministério da Saúde; 2020 [atualizado 2021 Jun 26] [citado 2021 Jun 7]. Disponível em: https:// covid.saude.gov.br/

11. Naidich JJ, Boltyenkov A, Wang JJ, Chusid J, Hughes D, Sanelli PC. Impact of the Coronavirus Disease 2019 (COVID-19) Pandemic on Imaging Case Volumes. J Am Coll Radiol. 2020;17(7):865-72.

12. Cavallo JJ, Forman HP. The economic impact of the COVID-19 pandemic on radiology practices. Radiology. 2020;296(3):E141-E4.

13. Tan KK, Lau J. Cessation of cancer screening: an unseen cost of the COVID-19 pandemic? Eur J Surg Oncol. 2020;46(11):2154-5.

14. Tsai HY, Chang YL, Shen CT, Chung WS, Tsai HJ, Chen FM. Effects of the COVID-19 pandemic on breast cancer screening in Taiwan. Breast. 2020;54:52-5.

15. Sickles EA, D'Orsi CJ, Bassett LW, Appleton CM, Berg WA, Burnside ES, et al. ACR BI-RADS ${ }^{\circledR}$ Atlas. Breast Imaging Reporting and Data System. 5th ed. Reston (USA): American College of Radiology; 2013. p. 179-83.

16. Kirkwood BR, Sterne JA. Essential medical statistics:11. 2nd ed. Massachusetts (USA): Blackwell Publisher; 2003. p. 13-468.

17. Andersson C, Gerds T, Fosbøl E, Phelps M, Andersen J, Lamberts M, et al Incidence of new-onset and worsening heart failure before and after the COVID-19 epidemic lockdown in Denmark: a nationwide cohort study. Circ Hear Fail. 2020;13(6):e007274.

18. Al-Thoubaity FK. Molecular classification of breast cancer: a retrospective cohort study. Ann Med Surg (Lond). 2019;49:44-8.

19. Dinmohamed AG, Visser O, Verhoeven RH, Louwman MW, van Nederveen FH, Willems SM, et al. Fewer cancer diagnoses during the COVID-19 epidemic in the Netherlands. Lancet Oncol. 2020; $21(6): 750-51$. Erratum in: Lancet Oncol. 2020 May 4.

20. Cancer Research UK. Together we will beat cancer. Urgent cancer referrals being turned down during coronavirus pandemic. London: Cancer Research UK; 2020 [updated 2020 July 8] [cited 2021 Jul 16]. Available from: https:// news.cancerresearchuk.org/2020/07/08/urgent-cancer-referrals-beingturned-down-during-coronavirus-pandemic/

21. Maringe M, Spicer J, Morris M, Purushotham A, Nolte E, Sullivan R, et al. The impact of the COVID-19 pandemic on cancer deaths due to delays in diagnosis in England, UK: a national, population-based, modelling study. Lancet Oncol. 2020;21 (8):1023-34. Erratum in: Lancet Oncol. 2021;22(1):e5.

22. Yokoo P, Silva MC, Castro AA, Fonseca EK, Martins KM, Queiroz MR, et al. Quality and safety innovations in the Radiology Department during the COVID-19 pandemic: a Latin American experience. einstein (São Paulo). 2020:18:eGS5832. 